J Immigr Minor Health. 2016 June ; 18(3): 624-635. doi:10.1007/s10903-015-0216-y.

\title{
Duration of US Residence and Obesity Risk in NYC Chinese Immigrants
}

\author{
Aimee Afable ${ }^{1}$, Ming-Chin Yeh ${ }^{1}$, Tushar Trivedi ${ }^{1}$, Erin Andrews ${ }^{1}$, and Judith Wylie-Rosett ${ }^{1}$ \\ ${ }^{1}$ Department of Community Health Sciences, SUNY Downstate School of Public Health, 450 \\ Clarkson Avenue, Mail Stop Code 43, Brooklyn, NY 11203, USA
}

\begin{abstract}
We evaluated whether duration of time in the US is associated with obesity risk in NYC Chinese immigrants. We analyzed cross-sectional survey data on 2072 men and women. Duration of US residence was categorized into $5,6-15$, and 15 years and over. Obesity was defined using WHO Asian standards: BMI of $27.5 \mathrm{~kg} / \mathrm{m}^{2}$ or greater. Diet and physical activity (PA) were assessed as potential explanatory variables. After adjusting for covariates, increased time in the US was associated with an increased obesity risk (OR 1.49; $95 \%$ CI 1.06, 2.08 for 15 years or more vs. $\mathbf{5}$ years); and in separate analysis, with having reported no work related PA (OR 0.76; $95 \%$ CI 0.59, 0.99). Findings suggest that increased time living in the US is associated with an increased obesity risk, a finding possibly explained by a shift to more sedentary lifestyle characteristic of the transition of immigrants to the US.
\end{abstract}

\section{Keywords}

Obesity; Chinese-origin; Assimilation; Acculturation

\section{Introduction}

Obesity is increasing in the US [1,2] and in many regions around the world including Asia [3-8] and Latin America [9] due to increasing wealth and urbanization [10]. These two regions also are the biggest contributors of immigrants to the US [11-13]. Because immigrant populations experience rapid change in exposures they provide a unique opportunity to study the impact of environmental change on the progression to obesity.

US immigrants are a dynamic population. There are 40 million immigrants in the US, representing a twofold increase in just two decades (1990-2010), and a growth rate that is unparalleled in US history [14]. Recent data indicate that Asia has now replaced Latin America as the major region of origin for the foreign-born population in the US. For example, among foreign-born population arriving 2008 or later, over $40 \%$ originate from Asia, compared to $25 \%$ from Mexico or Central America [15]. Among the newly arrived from Asia, Chinese-origin immigrants constitute the largest proportion [15].

Correspondence to: Aimee Afable.

Aimee Afable, Aimee.afable-munsuz@ downstate.edu. 


\section{Immigrant Health Advantage}

It is well-documented that immigrants arrive with a health advantage despite an adverse socio-economic profile [16-19]. One leading explanation for this advantage is that immigrants may compose a selected group who are healthier than their counterparts left behind in their origin country [20]. A second explanation is that the cultural orientation immigrants bring with them to the US protects them from adverse health outcomes. It has been suggested that the protective culture of immigrants encourages healthy behaviors and strong social support systems; facilitates access to health information and health systems; and reinforces positive health norms [21, 22]. For example, strong evidence suggests that the BMI of recent immigrants is lower, when compared to US natives [23, 24]. Supporting this pattern are studies showing higher fruit and vegetable intake [25] and certain forms of physical activity [26] among immigrants relative to US born. However, studies also suggest that this initial health advantage erodes over time, a process sometimes referred to as "unhealthy assimilation" [23].

\section{Focus on Obesity in Chinese-Origin Population}

Our study asks whether assimilation is associated with obesity risk using data from a large epidemiological study of Chinese immigrants living in NYC, an understudied population with high prevalence of both diabetes and impaired fasting glucose [27]. Several studies have examined the question of whether longer US residence is associated with increased risk of obesity in US immigrants [24, 28-30]. Some studies have focused on Asian populations, but have relied on nationally representative datasets, making it challenging to stratify by country of origin [24]. In a 2010 systematic review of time in the US and obesity in US immigrants, out of 15 studies conducted through 2008, only one study reported stratified data on Chinese adults; however this study did not present detailed analysis on time in the US and obesity risk by country of origin [24]. To our knowledge only one previous study published after the 2010 review presents data on Chinese separately; and this study finds a positive association between increasing generations and BMI using data from the National Latino and Asian American Survey [31].

Building on our prior work [32], we focus on a Chinese-origin immigrant population living in NYC. The Chinese population in New York City (NYC) has more than doubled in the past 20 years, making it one of the fastest growing immigrant groups in NYC [33, 34]. From a national perspective, in the last decade, the Asian population grew faster than any other race/ethnic group and the Chinese represent the largest ethnic group among all Asians [35].

Obesity growth worldwide has been attributed to westernization of lifestyles [36-38], and since Chinese immigrants are moving to a more western society in the US, it would be reasonable to assume that their obesity risk will be heightened with longer time in the US. Following this logic, we ask whether increased time in the US is associated with an increased obesity risk and if so, does increased caloric intake and/or a decline in physical activity explain the increased obesity risk? 


\section{Methods}

We conducted an analysis using data from the Chinese American Cardiovascular Health Assessment (CHA CHA), a cross-sectional epidemiological survey among 2072 immigrant Chinese Americans living in New York City [27]. The study was approved by the Institutional Review Boards at the Albert Einstein College of Medicine and NY Downtown Hospital. Study participants were recruited by the Chinese Community Partnership for Health $(\mathrm{CCPH})$ as a community cardiovascular screening initiative. The $\mathrm{CCPH}$ disseminated information about the screening program through the Chinese language media as well as senior centers, and businesses located in the Chinese communities in lower Manhattan and Sunset Park Brooklyn. The CCPH staff scheduled study appointments, which were conducted in NY Downtown Hospital's Manhattan and Brooklyn ambulatory care sites.

During the scheduled clinic appointments, trained CCHP staff obtained fasting blood for assessing cardiometabolic risk, anthropometric measures using standardized procedures, and collected participants' sociodemographic and behavioral information. Anthropometric measurements included height and weight and behavioral measures included self-reported physical activity [39] and diet [40].

\section{Measures}

\section{Years in the United States}

Following previous research on time in the US and obesity, a categorical variable with the three cut offs ( $5,6-15,>15$ years) was created to capture exposure to the United States, and also as a proxy for assimilation [23, 24].

\section{Measure of Obesity}

At the clinical visit, trained examiners took height and weight measurements from each subject. This information was used to calculate body mass index (BMI), by dividing weight in kilograms by height in meters squared $\left(\mathrm{kg} / \mathrm{m}^{2}\right)$. Consistent with the definition of obesity by the Asian standards, obesity was defined as BMI of $27.5 \mathrm{~kg} / \mathrm{m}^{2}$ or greater [27, 41].

\section{Physical Activity}

The Global Physical Activity Questionnaire (GPAQ) [42] developed by WHO was used to collect information on physical activity on participants in three settings (or domain): (1) Activity at work; (2) Travel to and from places; and (3) Recreational activities. A series of questions for each domain were asked based on a skip pattern of the preceding question, and metabolic equivalents (METs) for every activity for all participants were calculated. All participants replied to the first question in each domain (i.e. Do you do any kind of vigorous/ moderate activity at work that causes large increase in breathing or heart rate?; Do you walk or use bicycle for at least 10 min to get to and from places?; Do you do any vigorous/ moderate recreational physical activity for at least 10 min continuously that that causes large increase in breathing or heart rate?). Only 20-40\% participants reported being involved in some type of moderate or vigorous physical activity [20\% in travel related $(n=411), 25 \%$ in work related $(\mathrm{n}=511)$, and $39 \%(\mathrm{n}=811)$ in leisure time physical activity], and were 
asked subsequent questions related to frequency or time spent on those activities per week. Because information on METs could only be calculated for only a small proportion of our sample, in our final analytical models we kept our measurement for physical activity for all these three settings at a crude level i.e. Work related physical activity: Yes/No; Travel related physical activity: Yes/No; Leisure time physical activity (LTPA): Active (those who replied "yes" to recreational activities)/Inactive (those who replied "no" to recreational activities).

Leisure Time Physical Activity was categorized as Active for those who replied Yes to the question: "Do any moderate or vigorous PA for more than 10 min causing increase in heart rate or breathing" and those who answered No were categorized as Inactive. Work Related Physical Activity was categorized as Yes for those who replied Yes to the question: (1) "Does your work involve vigorous activity that causes large increase in breathing or heart rate"; or (2) "Does your work involve moderate-intensity activity that causes small increases in breathing or heart rate such as brisk walking or carrying light loads for at least $10 \mathrm{~min}$ continuously?" and as No for those who answered No to either question. Travel Related Physical Activity was categorized as Yes for those who replied Yes to the question: "Do you walk or use a bicycle (pedal cycle) for at least 10 min continuously to get to and from places?" and No for those who replied no to the above question.

\section{Diet}

Food frequency questionnaire (FFQ) [40] was used at the time of the interview to collect dietary information for each participant. Respondents estimated their consumption frequency over the previous year for 96 foods. Referent portion sizes were available to aid in portion size identification and the frequency of foods were open ended. Nutrient intake was estimated as the product of each food's consumption frequency and amount (in specified units) as reported on the FFQ, number of grams per food unit, and nutrient content per 100 $\mathrm{g}$, summed over all food items. Data collected from the food frequency questionnaire were averaged to produce an estimate of daily energy (kcal/day) and percent kcal from fat [40].

\section{Other Covariates}

We considered a number of covariates as possible confounders for the association between obesity and the time lived in the United States. These included socio-demographic variables such as age, sex, education level, employment status, and health insurance [23, 24].

\section{Statistical Methods}

We used SAS 9.3 (SAS Institute, Cary, NC) to perform all statistical analyses. We calculated the frequency and means of the study population characteristics and health related risk behaviors (diet and physical activity) by the years lived in the United States. Chi squared test was used to assess whether differences were statistically significant. All Chi square estimates are unadjusted.

Multiple logistic regression analysis was used to evaluate the association between the categorical variable for years lived in the US and four different models: obesity, leisure-time physical activity (LTPA), work-related PA and travel PA. We first calculated crude odds ratio for all dependent variables based on years lived in the US, and then we in our second step 
we added age. Finally, we ran an adjusted model, which included age as well and other potential confounders (socio-demographic variables), to examine the influence each set of variables had on the ORs associated with years lived in the US.

To assess whether sex is an effect modifier in the association between years lived in the US and all of our dependent variables [23, 24], we evaluated the significance of an interaction term between sex and years lived in the US in all of our models. Interaction terms in all models were insignificant: obesity $(p$ value $=0.28)$, LTPA $(p$ value $=0.470$, work PA $(p$ value $=0.15)$, and travel PA ( $p$ value $=0.27$ ). Thus, we did not stratify our analysis by gender.

\section{Results \\ Demographics}

Sample characteristics are presented in Table 1 . The majority of the sample was female (53\%), had some high school education. Almost $42 \%$ had government health insurance while $38 \%$ were uninsured. The prevalence of obesity (BMI > 27) was $16 \%$ (19.6\% in women and $13 \%$ in men). The average age of migration to the United States was 39.4 years old and $36.7 \%$ of the sample resided in the US for $6-15$ years while $34.3 \%$ who lived in the US for $>15$ years.

\section{Duration of US Residence and Main Study Variables}

Chi squared tests revealed statistically significant differences between the three designated immigration groups: 5, 6-15 and $>15$ years. Those who lived in the US $>15$ years were on average 9 and 11 years older than those living in the US for $6-15$ and 5 years, respectively $(p<0.001)$.

Those who lived in the US for the longest duration ( $>15$ years), were the most active in performing leisure time physical activity for more than $10 \min (p<0.001)$ however, had the highest percentage of type II diabetes mellitus $(11.3 \%, p<0.001)$, highest average BMI $(24.3, p<0.001)$, and highest prevalence of obesity $(19.3 \%, p=0.006)$ than those living in the US for 5 and $6-15$ years.

There was no statistically significant difference between the kilocalories consumed by each group ( $5,6-15$ and $>15$ years). Those without health insurance comprised almost half of those living in the US for 5 and 6-15 years. Employment status (64.5\%) and college education (43.4\%) were greatest among those living in the US for 6-15 years (Table 2).

\section{Duration of US Residence and Obesity}

Table 3 confirmed bivariate analyses indicating that those living in the US $>15$ years had greater odds of being obese (BMI > 27) compared to other those living in the US $\mathbf{5}$ years, controlling for age, gender, employment status, health insurance coverage and education. Those without formal education had greater odds of being obese when compared to those of lower educational levels, controlling for covariates. Men and those 60 years and older had greater odds of being obese than women and other age groups, respectively, when controlling for age, gender, employment status, health insurance coverage and education. 


\section{Duration of US Residence and Leisure-Time Physical Activity}

Table 4 shows that those living in the US for $>15$ years have the greatest odds for being physically active compared to immigrants living in the US for $\mathbf{5}$ years, controlling for age, gender, employment status, health insurance coverage and education. The odds of being physically active were highest among housewives (49\%) and unemployed (48\%), when compared to those employed, controlling for age, gender, employment status, health insurance coverage and education. When adjusting for age, those 60 years and older had the lowest odds of being physically active in comparison to other age groups. The odds of men and the college educated being physically active were higher compared to women and other educational groups, when adjusting for age, gender, employment status, health insurance coverage and education.

\section{Duration of US Residence and Work-Related Physical Activity}

When adjusting for age, gender, health insurance coverage and education, there were decreased odds associated with physically activity at work among immigrants living in the US for 6-15 years, when compared to immigrants living in the US for 5 years. Similar to previous analysis, when adjusting for age, gender, health insurance coverage and education, men had almost 2.5 times the odds of being physically active at work than women. The odds of being physically active at work was 52 and $56 \%$ higher for elementary and high school educated in comparison with those who have a college education when adjusting for age, gender, health insurance coverage and education (Table 5).

\section{Duration of US Residence and Travel Related Physical Activity}

In Table 6, when adjusting for age, gender, employment status, health insurance coverage and education, the odds for doing at least 10 min of travel related physical activity was lower for men and the uninsured compared to women and those with government health insurance. Those 60 years and older had a $86 \%$ greater odds for doing at least 10 min of travel related physical activity than younger counterparts. Retired persons had a higher odds of doing more than 10 min of travel related physical activity than those who were employed.

Gender did not modify any of the potential relationships associated with years living in the US: work related physical activity, leisure time physical activity and obesity. The tests for interaction between gender and years living in the US were not statistically significant.

\section{Discussion}

Our study suggests that longer US residence is associated with an elevated risk of obesity, using Asian obesity standards, among Chinese immigrants living in NYC: those who have lived in the US 15 years or longer have a heightened risk, compared to those living in the US 5 years or less. This finding is consistent with past studies which have shown an elevated obesity risk at the 10 and 15 years duration of residence cutoff points [23, 32, 43] This association is not influenced by SES and demographic factors measured in our study. Of the SES and demographic factors we examine, women (compared to men) and individuals who reported no schooling were at an increased risk for obesity. 
We aimed to examine whether increased caloric intake and/or a decline in physical activity might explain the increased obesity risk. In bivariate comparisons, we found that total kilocalories did not vary significantly by our duration of residence categories (Table 2). In contrast, there were significant differences in physical activity by our duration of residence categories. In adjusted analyses, longer duration of US residence was associated with a greater likelihood of any leisure-time physical activity (vs. none), but lower likelihood of work related physical activity, a finding consistent with previous literature [26]. Therefore, our study suggests that lower levels of work-related PA might explain elevated obesity risk in immigrants with longer US residence.

From a broader perspective, longer duration of US residence can be viewed as a marker of cumulative exposure to a new social, cultural, and physical environment. In this regard, our study lends support to the notion that assimilation to the US has an adverse effect on health. Relating our findings to global changes in lifestyles and patterns in obesity and diabetes, however, may help elucidate some of the causal pathways implicated in this process of unhealthy assimilation $[38,44,45]$. Intra-country migrants who move from rural to urban areas, or who transition from poverty to affluence, for example, can take on more sedentary jobs, markedly different from their former labor-intensive work and adopt less healthy diets [46, 47]. Migrants who move from their home country to the US, particularly major urban destinations such as New York City (NYC), and seek better economic opportunities undergo similar, perhaps more dramatic changes. To the extent that Chinese immigrants are integrating into more sedentary occupations upon settling in NYC, it makes sense that workrelated PA declines with greater time in the US and that this trend might explain higher obesity risk.

\section{Limitations and Considerations for Future Research on Immigrant Health}

We used convenience sampling. A comparison of our study sample to the NYC Chinese adult population, using the 2006-2010 American Community Survey, indicate that overall our sample was older but educational and employment levels were relatively comparable $[48,49]$. Also $97 \%$ of our sample was foreign-born compared to $76 \%$ of the NYC Chinese adult population $[48,49]$. Because this study relies on cross-sectional data used from the CHA CHA study, it is beyond our scope to estimate temporal effects, which would help to establish causality, and allow us to conduct a formal causal mediation analysis linking diet and physical activity to obesity risk [50]. Further, cross-sectional studies of immigrants do not allow the study of key dynamic aspects of immigration at the individual level [51]. Because we have a cross-section of different migrant cohorts in our study, it is possible that they arrive to the US with a different migration experience [23]. Family inter-generational studies (parents and their offspring), prospective cohort studies of new immigrants followed at regular intervals [51], and bi-national studies of migrants and their non-migrant counterparts $[52,53]$ would allow us to control for heterogeneity by place of origin, to study adaptation over time, and to assess immigrant selection.

Chronic exposure to the US built environment (e.g. walkability, proximity to grocery stores, public transit), which is increasingly characterized as "obesogenic" [54, 55] may also play an important role in accelerating the development of obesity in US immigrants [56]. Also 
within an urban context, such as NYC, neighborhood crime, un-familiarity with the physical surroundings may also discourage immigrants from maintaining an active lifestyle [57-60]. However, our survey did not collect information on these variables.

\section{Conclusion}

Relationships between measures of assimilation, such as duration of US residence, and health are complex [17], and both negative and positive associations between assimilation and health have been observed [23, 25, 26, 43, 61-65]. This evidence from the health literature is not surprising given the heterogeneity of assimilation processes in US immigrants as described by scholars of migration [66]. Our study adds to the evidence on the adverse associations between accumulating exposure to US environment and obesity risk and other health indicators in US immigrant. Although we provide preliminary evidence that the elevated obesity risk in immigrants might be explained by a shift to more sedentary occupations, a more systematic study of the causal mechanisms linking assimilation to poor health is called for. We also suggest that such examinations would benefit when placed within the context of the global epidemic of obesity.

\section{Acknowledgments}

This research was supported in part by funding from the American Heart Association and NIH Grants R01HL077809, UL1 RR025750 and P60 DK020541.

\section{References}

1. Sturm R, Hattori A. Morbid obesity rates continue to rise rapidly in the United States. Int J Obes. 2013; 37(6):889-891.

2. Ogden CL, Carroll MD, Kit BK, Flegal KM. Prevalence of childhood and adult obesity in the United States, 2011-2012. JAMA. 2014; 311(8):806-814. [PubMed: 24570244]

3. Gu D, Reynolds K, Wu X, et al. Prevalence of the metabolic syndrome and overweight among adults in China. Lancet. 2005; 365(9468):1398-1405. [PubMed: 15836888]

4. Wang Y, Mi J, Shan XY, Wang QJ, Ge KY. Is China facing an obesity epidemic and the consequences? The trends in obesity and chronic disease in China. Int J Obes (Lond). 2007; 31(1): 177-188. [PubMed: 16652128]

5. Ramachandran A, Ma RC, Snehalatha C. Diabetes in Asia. Lancet. 2010; 375(9712):408-418. [PubMed: 19875164]

6. Hou X, Liu Y, Lu H, et al. Ten-year changes in the prevalence of overweight, obesity and central obesity among the Chinese adults in urban Shanghai, 1998-2007-comparison of two crosssectional surveys. BMC Public Health. 2013; 13(1):1064. [PubMed: 24215220]

7. Du T, Sun X, Yin P, Huo R, Ni C, Yu X. Increasing trends in central obesity among Chinese adults with normal body mass index, 1993-2009. BMC Public Health. 2013; 13(1):327. [PubMed: 23575244]

8. Chan JC, Malik V, Jia W, et al. Diabetes in Asia: epidemiology, risk factors, and pathophysiology. JAMA. 2009; 301(20):2129-2140. [PubMed: 19470990]

9. Rtveladze K, Marsh T, Barquera S, et al. Obesity prevalence in Mexico: impact on health and economic burden. Public Health Nutr. 2014; 17(01):233-239. [PubMed: 23369462]

10. Ramachandran A, Snehalatha C, Shetty AS, Nanditha A. Trends in prevalence of diabetes in Asian countries. World J Diabetes. 2012; 3(6):110. [PubMed: 22737281]

11. Villalpando S, Rojas R, Shamah-Levy T, et al. Prevalence and distribution of type 2 diabetes mellitus in Mexican adult population: a probabilistic survey. Salud Publica Mex. 2010; 52(Suppl 1):S19-S26. [PubMed: 20585724] 
12. Yang SH, Dou KF, Song WJ. Prevalence of diabetes among men and women in China. N Engl J Med. 2010; 362(25):2425-2426. author reply 2426. [PubMed: 20578276]

13. Soria ML, Sy RG, Vega BS, et al. The incidence of type 2 diabetes mellitus in the Philippines: a 9year cohort study. Diabetes Res Clin Pract. 2009; 86(2):130-133. [PubMed: 19766344]

14. Malone, N.; Baluja, K.; Costanzo, J.; Davis, C. The foreign-born population: 2000. US Census Bureau; 2003.

15. Walters, NP.; Trevelyan, EN. The newly arrived foreign-born population of the United States: 2010. US Census Bureau; 2011.

16. Markides, KS.; Gerst, K. Handbook of sociology of aging. New York: Springer; 2011. Immigration, aging, and health in the United States; p. 103-116.

17. Markides, KS. Migration and health. In: Smelser, NJ.; Baltes, B., editors. International encyclopedia of the social and behavioral sciences. Amsterdam: Elsevier; 2001. p. 799-803.

18. Markides KS, Coreil J. The health of Hispanics in the southwestern United States: an epidemiologic paradox. Public Health Rep. 1986; 101(3):253-265. [PubMed: 3086917]

19. Singh GK, Siahpush M. Ethnic-immigrant differentials in health behaviors, morbidity, and causespecific mortality in the United States: an analysis of two national data bases. Hum Biol. 2002; 74(1):83-109. [PubMed: 11931581]

20. Marmot MG, Adelstein AM, Bulusu L. Lessons from the study of immigrant mortality. Lancet. 1984; 1(8392):1455-1457. [PubMed: 6145889]

21. Cattell V. Poor people, poor places, and poor health: the mediating role of social networks and social capital. Soc Sci Med. 2001; 52(10):1501-1516. [PubMed: 11314847]

22. Kawachi, I.; Berkman, L. Social cohesion, social capital, and health. In: Berkman, L.; Kawachi, I., editors. Social epidemiology. Oxford: Oxford University Press; 2000. p. 174-190.

23. Antecol H, Bedard K. Unhealthy assimilation: do immigrants converge to American health status levels? Demography. 2006; 43(2):337-360. [PubMed: 16889132]

24. Oza-Frank R, Cunningham SA. The weight of US residence among immigrants: a systematic review. Obes Rev. 2010; 11(4):271-280. [PubMed: 19538440]

25. Ayala GX, Baquero B, Klinger S. A systematic review of the relationship between acculturation and diet among Latinos in the United States: implications for future research. J Am Diet Assoc. 2008; 108(8):1330-1344. [PubMed: 18656573]

26. Afable-Munsuz A, Ponce N, Perez-Stable E, Rodriguez M. Immigrant generation and physical activity among Mexican, Chinese and Filipino adults in the US. Soc Sci Med. 2010; 70(12):19972005. [PubMed: 20378226]

27. Rajpathak SN, Wylie-Rosett J. High prevalence of diabetes and impaired fasting glucose among Chinese immigrants in New York City. J Immigr Minor Health. 2011; 13(1):181-183. [PubMed: 20533090]

28. Bharmal N, Kaplan RM, Shapiro MF, et al. The association of duration of residence in the United States with cardiovascular disease risk factors among South Asian immigrants. J Immigr Minor Health. 2014:1-10. [PubMed: 23054547]

29. Daouli J, Davillas A, Demoussis M, Giannakopoulos N. Obesity persistence and duration dependence: evidence from a cohort of US adults (1985-2010). Econ Hum Biol. 2014; 12:30-44. [PubMed: 24012525]

30. Roshania R, Narayan KM, Oza-Frank R. Age at arrival and risk of obesity among US immigrants. Obesity. 2008; 16(12):2669-2675. [PubMed: 18846044]

31. Bates LM, Acevedo-Garcia D, Alegria M, Krieger N. Immigration and generational trends in body mass index and obesity in the United States: results of the National Latino and Asian American Survey, 2002-2003. Am J Public Health. 2008; 98(1):70-77. [PubMed: 18048787]

32. Yeh MC, Fahs M, Shelley D, Yerneni R, Parikh NS, Burton D. Body weight and length of residence in the US among Chinese Americans. J Immigr Minor Health. 2009; 11(5):422-427. [PubMed: 18085438]

33. US Census Bureau. American Community Survey, 2000 American Community Survey 1-Year Estimates, Table DP-1, Profile of General Demographic Characteristics: 2000; using American FactFinder. 2015 Feb 24. http://factfinder2.census.gov 
34. US Census Bureau. Demographic Characteristics-New York City 1990 and 2000 Census; 2000 Census SF1, 1990 Census STF1, STF4. 2015 Feb 24. http://www.nyc.gov/html/dcp/pdf/census/ demonyc.pdf

35. Hoeffel, EM.; Rastogi, S.; Kim, MO.; Shahid, H. The asian population: 2010. US Census Bureau; 2012.

36. Fujimoto, WY.; Bergstrom, RW.; Boyko, EJ., et al. Diabetes Res Clin Pract. Vol. 24. Washington: 1994. Diabetes and diabetes risk factors in second- and third-generation Japanese Americans in Seattle; p. S43-S52.

37. Kawate R, Yamakido M, Nishimoto Y, Bennett PH, Hamman RF, Knowler WC. Diabetes mellitus and its vascular complications in Japanese migrants on the Island of Hawaii. Diabetes Care. 1979; 2(2):161-170. [PubMed: 520120]

38. Popkin BM, Gordon-Larsen P. The nutrition transition: worldwide obesity dynamics and their determinants. Int J Obes Relat Metab Disord. 2004; 28(Suppl 3):S2-S9. [PubMed: 15543214]

39. Institute K. [Accessed 24 May 2014] International Physical Activity Questionnaires (IPAQ). 2002. https://sites.google.com/site/theipaq/questionnaire_links

40. Tseng M, Hernández T. Comparison of intakes of US Chinese women based on food frequency and 24-hour recall data. J Am Diet Assoc. 2005; 105(7):1145-1148. [PubMed: 15983537]

41. Who EC. Appropriate body-mass index for Asian populations and its implications for policy and intervention strategies. Lancet. 2004; 363(9403):157. [PubMed: 14726171]

42. Cleland CL, Hunter RF, Kee F, Cupples ME, Sallis JF, Tully MA. Validity of the global physical activity questionnaire (GPAQ) in assessing levels and change in moderate-vigorous physical activity and sedentary behaviour. BMC Public Health. 2014; 14:1255. [PubMed: 25492375]

43. Oza-Frank R, Stephenson R, Venkat Narayan KM. Diabetes prevalence by length of residence among US immigrants. J Immigr Minor Health. 2011; 13(1):1-8. [PubMed: 19688263]

44. Kelly T, Yang W, Chen CS, Reynolds K, He J. Global burden of obesity in 2005 and projections to 2030. Int J Obes (Lond). 2008; 32(9):1431-1437. [PubMed: 18607383]

45. Shaw JE, Sicree RA, Zimmet PZ. Global estimates of the prevalence of diabetes for 2010 and 2030. Diabetes Res Clin Pract. 2010; 87(1):4-14. [PubMed: 19896746]

46. Kutty VR, Soman CR, Joseph A, Pisharody R, Vijayakumar K. Type 2 diabetes in southern Kerala: variation in prevalence among geographic divisions within a region. Natl Med J India. 2000; 13(6): 287-292. [PubMed: 11209482]

47. Misra A, Ganda OP. Migration and its impact on adiposity and type 2 diabetes. Nutrition. 2007; 23(9):696-708. [PubMed: 17679049]

48. US Census Bureau. American Community Survey, 2010 American Community Survey 1-Year Estimates, Table S0201, Selected Population Profile in the United States; generated by Erin Andrews; using American FactFinder. 2015 Feb 24. http://factfinder2.census.gov

49. US Census Bureau. American Community Survey, 2010 American Community Survey 1-Year Estimates, Tables B5003 B15001 B23001; generated by Erin Andrews; using American FactFinder. 2015 Feb 24. http://factfinder2.census.gov

50. Baron RM, Kenny DA. The moderator-mediator variable distinction in social psychological research: conceptual, strategic, and statistical considerations. J Pers Soc Psychol. 1986; 51(6): 1173-1182. [PubMed: 3806354]

51. Jasso G, Massey DS, Rosenzweig MR, Smith JP. The New Immigrant Survey Pilot (NIS-P): overview and new findings about US legal immigrants at admission. Demography. 2000; 37(1): 127-138. [PubMed: 10748994]

52. Ullmann SH, Goldman N, Massey DS. Healthier before they migrate, less healthy when they return? The health of returned migrants in Mexico. Soc Sci Med. 2011; 73(3):421-428. [PubMed: 21729820]

53. Lyngdoh T, Kinra S, Shlomo YB, et al. Sib-recruitment for studying migration and its impact on obesity and diabetes. Emerg Themes Epidemiol. 2006; 3:2. [PubMed: 16533387]

54. Giskes K, van Lenthe F, Avendano-Pabon M, Brug J. A systematic review of environmental factors and obesogenic dietary intakes among adults: are we getting closer to understanding obesogenic environments? Obes Rev. 2010; 12(5):e95-e106. [PubMed: 20604870] 
55. Sallis JF, Bowles HR, Bauman A, et al. Neighborhood environments and physical activity among adults in 11 countries. Am J Prev Med. 2009; 36(6):484-490. [PubMed: 19460656]

56. Auchincloss AH, Diez Roux AV, Mujahid MS, Shen M, Bertoni AG, Carnethon MR. Neighborhood resources for physical activity and healthy foods and incidence of type 2 diabetes mellitus: the Multi-Ethnic study of Atherosclerosis. Arch Intern Med. 2009; 169(18):1698-1704. [PubMed: 19822827]

57. Lopez RP, Hynes HP. Obesity, physical activity, and the urban environment: public health research needs. Environ Health. 2006; 5(1):25. [PubMed: 16981988]

58. Humpel N, Owen N, Leslie E. Environmental factors associated with adults' participation in physical activity: a review. Am J Prev Med. 2002; 22(3):188-199. [PubMed: 11897464]

59. Brownson RC, Chang JJ, Eyler AA, et al. Measuring the environment for friendliness toward physical activity: a comparison of the reliability of 3 questionnaires. Am J Public Health. 2004; 94(3):473. [PubMed: 14998817]

60. Seefeldt V, Malina RM, Clark MA. Factors affecting levels of physical activity in adults. Sports Med. 2002; 32(3):143-168. [PubMed: 11839079]

61. Mainous AG 3rd, Majeed A, Koopman RJ, et al. Acculturation and diabetes among Hispanics: evidence from the 1999-2002 National Health and Nutrition Examination Survey. Public Health Rep. 2006; 121(1):60-66. [PubMed: 16416699]

62. Ahmed AT, Quinn VP, Caan B, Sternfeld B, Haque R, Van Den Eeden SK. Generational status and duration of residence predict diabetes prevalence among Latinos: the California Men's Health Study. BMC Public Health. 2009; 9:392. [PubMed: 19840393]

63. Lara M, Gamboa C, Kahramanian M, Morales L, Bautista D. Acculturation and Latino Health in the Unites States: a review of the literature and its sociopolitical context. Annu Rev Public Health. 2005; 26:367-397. [PubMed: 15760294]

64. Hazuda HP, Haffner SM, Stern MP, Eifler CW. Effects of acculturation and socioeconomic status on obesity and diabetes in Mexican Americans. The San Antonio Heart Study. Am J Epidemiol. 1988; 128(6):1289-1301. [PubMed: 3195568]

65. Kandula NR, Diez-Roux AV, Chan C, et al. Association of acculturation levels and prevalence of diabetes in the multi-ethnic study of atherosclerosis (MESA). Diabetes Care. 2008; 31(8):16211628. [PubMed: 18458142]

66. Portes A, Zhou M. The new second generation: segmented assimilation and its variants. Ann Am Acad. 1993 Nov.530:74-96. 1990. 


\section{Table 1}

Characteristics of the sample population $(n=2072)$

\begin{tabular}{|c|c|c|c|}
\hline Characteristics & Overall (\%) & Male (\%) & Female (\%) \\
\hline Total sample & & 47.25 & 52.75 \\
\hline Age, mean (SE) & $52.69(0.30)$ & $54.21(0.45)$ & $51.32(0.40)$ \\
\hline Mean age at migration (SE) & $39.44(0.30)$ & $40.38(0.44)$ & $38.60(0.41)$ \\
\hline \multicolumn{4}{|l|}{ Age at migration } \\
\hline$<13$ years & 1.40 & 1.02 & 1.74 \\
\hline$\geq 13$ years & 98.60 & 98.98 & 98.76 \\
\hline \multicolumn{4}{|l|}{ Employment status } \\
\hline Employed & 55.55 & 58.63 & 52.79 \\
\hline Unemployed & 11.20 & 15.32 & 7.50 \\
\hline Retired & 12.35 & 25.64 & 19.40 \\
\hline Housewife & 10.91 & 0.41 & 20.31 \\
\hline \multicolumn{4}{|l|}{ Education } \\
\hline No school & 1.25 & 0.51 & 1.92 \\
\hline Elementary (1-6 years) & 13.85 & 12.61 & 15.37 \\
\hline High school (7-12 years) & 51.16 & 50.66 & 51.60 \\
\hline College and above ( $>12$ years) & 33.74 & 36.67 & 31.11 \\
\hline \multicolumn{4}{|l|}{ Health insurance } \\
\hline None & 38.13 & 39.63 & 36.78 \\
\hline Government & 41.99 & 42.80 & 41.26 \\
\hline Private & 15.97 & 14.50 & 17.29 \\
\hline Others & 3.52 & 2.76 & 4.21 \\
\hline Unknown & 0.39 & 0.31 & 0.46 \\
\hline BMI, mean (SE) & $23.94(0.07)$ & $24.55(0.09)$ & $23.39(0.09)$ \\
\hline Total MET min/week, mean (SE) & $3400.78(113.86)$ & $4097.78(196.10)$ & $2767.85(121.10)$ \\
\hline \multicolumn{4}{|l|}{ Leisure time physical activity } \\
\hline Active & 39.41 & 44.74 & 34.13 \\
\hline Inactive & 60.81 & 55.26 & 65.87 \\
\hline \multicolumn{4}{|l|}{ Work related physical activity } \\
\hline Yes & 24.66 & 32.28 & 17.84 \\
\hline No & 75.34 & 67.72 & 82.16 \\
\hline \multicolumn{4}{|l|}{ Travel related physical activity } \\
\hline Yes & 19.84 & 21.45 & 18.39 \\
\hline No & 80.16 & 78.55 & 81.61 \\
\hline \multicolumn{4}{|l|}{ Obesity (BMI $\geq 27.5$ ) } \\
\hline Yes & 16.12 & 19.61 & 12.99 \\
\hline No & 83.88 & 80.39 & 87.01 \\
\hline \multicolumn{4}{|l|}{ Years lived in US } \\
\hline$\$$ years & 29.01 & 24.62 & 32.94 \\
\hline $6-15$ years & 36.73 & 38.51 & 35.13 \\
\hline
\end{tabular}




\begin{tabular}{llll}
\hline Characteristics & Overall $(\%)$ & Male $(\%)$ & Female $(\boldsymbol{\%})$ \\
\hline$>15$ years & 34.27 & 36.87 & 31.93 \\
KCAL, mean (SE) & $1797.54(17.00)$ & $1946.81(25.58)$ & $1663.84(21.89)$ \\
\hline
\end{tabular}


Table 2

Characteristics of the sample population by years lived in the US $(n=2072)$

\begin{tabular}{|c|c|c|c|c|}
\hline & 5 years & $6-15$ years & $>15$ years & $p$ value \\
\hline Age, mean (SE) & $48.22(0.54)$ & $50.20(0.48)$ & $59.13(0.45)$ & $<0.001$ \\
\hline Total MET min/week, mean (SE) & $3556.89(223.8)$ & $3735.09(221.8)$ & $2928.27(137.6)$ & 0.007 \\
\hline Leisure time physical activity ${ }^{a}$ & & & & $<0.001$ \\
\hline Active & 34.28 & 36.79 & 45.77 & \\
\hline Inactive & 65.72 & 63.21 & 54.23 & \\
\hline Work related physical activity & & & & 0.004 \\
\hline Yes & 27.79 & 26.15 & 20.42 & \\
\hline No & 72.21 & 73.85 & 79.58 & \\
\hline Travel related physical activity & & & & 0.385 \\
\hline Yes & 20.63 & 20.76 & 18.17 & \\
\hline No & 79.37 & 79.24 & 81.13 & \\
\hline KCAL, mean (SE) & $1815.93(31.4)$ & $1833.84(28.5)$ & $1743.07(28.5)$ & 0.060 \\
\hline BMI, mean (SE) & $23.58(0.12)$ & $23.93(0.1)$ & $24.26(0.12)$ & $<0.001$ \\
\hline Obesity (BMI $\geq 27$ ) & & & & 0.006 \\
\hline Yes & 12.81 & 15.77 & 19.30 & \\
\hline No & 87.19 & 84.23 & 80.70 & \\
\hline Employment status & & & & $<0.001$ \\
\hline Employed & 58.90 & 64.52 & 43.10 & \\
\hline Unemployed & 15.47 & 11.17 & 7.61 & \\
\hline Retired & 12.81 & 13.27 & 40.14 & \\
\hline Housewife & 12.81 & 11.04 & 9.15 & \\
\hline Education & & & & $<0.001$ \\
\hline No school & 1.16 & 1.18 & 1.41 & \\
\hline Elementary (1-6 years) & 8.15 & 11.56 & 21.13 & \\
\hline High school ( $7-12$ years $)$ & 50.42 & 52.83 & 50.00 & \\
\hline College and above ( $>12$ years) & 40.27 & 43.43 & 27.46 & \\
\hline Health insurance & & & & $<0.001$ \\
\hline None & 48.42 & 48.09 & 18.73 & \\
\hline Government & 38.77 & 33.77 & 53.52 & \\
\hline Private & 9.32 & 14.32 & 23.38 & \\
\hline Others & 2.66 & 3.42 & 4.37 & \\
\hline Unknown & 0.83 & 0.39 & 0.00 & \\
\hline
\end{tabular}

a Leisure time physical activity; Those who replied Yes to the question: "Do any moderate or vigorous PA for more than 10 min causing increase in heart rate or breathing" were categorized as Active, and those who answered No were categorized as Inactive

J Immigr Minor Health. Author manuscript; available in PMC 2017 June 01. 
Table 3

Odds ratio for obesity (BMI 227.5) from crude and adjusted models $(\mathrm{n}=2072)$

\begin{tabular}{|c|c|c|c|}
\hline & Crude odds ratio & Adjusted odds ratio for obesity ${ }^{a}$ & Adjusted odds ratio for obesity $b$ \\
\hline \multicolumn{4}{|l|}{ Years lived in United States } \\
\hline$\leq 5$ years & Reference & Reference & Reference \\
\hline $6-15$ years & $1.27(0.92,1.71)$ & $1.24(0.91,1.68)$ & $1.18(0.86,1.62)$ \\
\hline$>15$ years & $1.62(1.19,2.19)$ & $1.48(1.07,2.03)$ & $1.49(1.06,2.08)$ \\
\hline \multicolumn{4}{|l|}{ Age } \\
\hline$\$ 40$ & & Reference & Reference \\
\hline $40-60$ & & $1.52(1.04,2.23)$ & $1.43(0.97,2.11)$ \\
\hline 260 & & $1.64(1.08,2.48)$ & $1.68(1.03 .2 .75)$ \\
\hline \multicolumn{4}{|l|}{ Gender } \\
\hline Female & & & Reference \\
\hline Male & & & $1.71(1.32,2.23)$ \\
\hline \multicolumn{4}{|l|}{ Employment status } \\
\hline Employed & & & Reference \\
\hline Unemployed & & & $0.94(0.63,1.40)$ \\
\hline Retired & & & $0.82(0.53,1.27)$ \\
\hline Housewife & & & $1.23(0.80,1.90)$ \\
\hline \multicolumn{4}{|l|}{ Education } \\
\hline No school & & & $3.16(1.31,7.62)$ \\
\hline Elementary (1-6 years) & & & $1.27(0.86,1.88)$ \\
\hline High school (7-12 years) & & & $1.29(0.97,1.71)$ \\
\hline College and above ( $>12$ years) & & & Reference \\
\hline \multicolumn{4}{|l|}{ Health insurance } \\
\hline Government & & & Reference \\
\hline Private & & & $0.69(0.47,1.03)$ \\
\hline Others & & & $1.25(0.66,2.37)$ \\
\hline None & & & $0.98(0.73,1.33)$ \\
\hline Unknown & & & $2.12(0.41,11.01)$ \\
\hline
\end{tabular}


Table 4

Odds ratio for being physically active (Yes to any LTPA) by years lived in US

\begin{tabular}{|c|c|c|c|}
\hline & $\begin{array}{l}\text { Crude odds } \\
\text { ratio }\end{array}$ & $\begin{array}{l}\text { Adjusted odds ratio for being physically } \\
\text { active }^{a}\end{array}$ & $\begin{array}{l}\text { Adjusted odds ratio for being physically } \\
\text { active }^{b}\end{array}$ \\
\hline \multicolumn{4}{|l|}{ Years lived in United States } \\
\hline 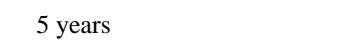 & Reference & Reference & Reference \\
\hline $6-15$ years & $1.16(0.89,1.39)$ & $1.13(0.90,1.42)$ & $1.17(0.92,1.47)$ \\
\hline$<15$ years & $1.61(1.29,2.02)$ & $1.73(1.41,2.27)$ & $1.82(1.46,2.44)$ \\
\hline \multicolumn{4}{|l|}{ Age } \\
\hline$\leq 40$ & & Reference & Reference \\
\hline $40-60$ & & $0.83(0.64,1.06)$ & $0.96(0.74,1.24)$ \\
\hline$\lcm{60}$ & & $0.74(0.55,0.98)$ & $0.71(0.49,1.02)$ \\
\hline \multicolumn{4}{|l|}{ Gender } \\
\hline Female & & & Reference \\
\hline Male & & & $1.55(1.27,1.88)$ \\
\hline \multicolumn{4}{|l|}{ Employment status } \\
\hline Employed & & & Reference \\
\hline Unemployed & & & $1.48(1.11,1.99)$ \\
\hline Retired & & & $1.14(0.80,1.60)$ \\
\hline Housewife & & & $1.49(1.08,2.05)$ \\
\hline \multicolumn{4}{|l|}{ Education } \\
\hline No school & & & $0.08(0.02,0.38)$ \\
\hline Elementary (1-6 years) & & & $0.43(0.32,0.59)$ \\
\hline High school (7-12 years) & & & $0.55(0.45,0.68)$ \\
\hline College and above ( $>12$ years) & & & Reference \\
\hline \multicolumn{4}{|l|}{ Health insurance } \\
\hline Government & & & Reference \\
\hline Private & & & $1.10(0.83,1.45)$ \\
\hline Others & & & $0.66(0.38,1.13)$ \\
\hline None & & & $0.84(0.67,1.05)$ \\
\hline Unknown & & & $0.84(0.19,3.70)$ \\
\hline
\end{tabular}

Physically active: Those who replied Yes to the question: "Do any moderate or vigorous PA for more than 10 min causing increase in heart rate or breathing" were categorized as Active, and those who answered No were categorized as Inactive

${ }^{a}$ Model was simultaneously adjusted for age

${ }^{b}$ Model was simultaneously adjusted for age, gender, employment status, health insurance coverage, education level 
Table 5

Odds ratio for being physically active at work (Yes to any work related PA) by years lived in US

\begin{tabular}{|c|c|c|c|}
\hline & $\begin{array}{l}\text { Crude odds } \\
\text { ratio }\end{array}$ & $\begin{array}{l}\text { Adjusted odds ratio for being } \\
\text { physically active } \\
\text { at work }{ }^{a}\end{array}$ & $\begin{array}{l}\text { Adjusted odds ratio for being physically active } \\
\text { at work } b\end{array}$ \\
\hline \multicolumn{4}{|l|}{ Years lived in United States } \\
\hline$\leq$ years & Reference & Reference & Reference \\
\hline $6-15$ years & $0.92(0.72,1.17)$ & $0.91(0.71,1.17)$ & $0.76(0.59,0.99)$ \\
\hline$>15$ years & $0.66(0.51,0.86)$ & $0.79(0.60,1.04)$ & $0.76(0.56,1.02)$ \\
\hline \multicolumn{4}{|l|}{ Age } \\
\hline$\leq 40$ & & Reference & Reference \\
\hline $40-60$ & & $1.35(1.02,1.79)$ & $1.26(0.94,1.69)$ \\
\hline 260 & & $0.47(0.33,0.67)$ & $1.18(0.78,1.79)$ \\
\hline \multicolumn{4}{|l|}{ Gender } \\
\hline Female & & & Reference \\
\hline Male & & & $2.45(1.94,3.09)$ \\
\hline \multicolumn{4}{|l|}{ Education } \\
\hline No school & & & $0.82(0.22,3.01)$ \\
\hline Elementary ( $1-6$ years) & & & $1.52(1.05,2.21)$ \\
\hline High school (7-12 years) & & & $1.56(1.22,2.01)$ \\
\hline College and above ( $>12$ years) & & & Reference \\
\hline \multicolumn{4}{|l|}{ Health insurance } \\
\hline Government & & & Reference \\
\hline Private & & & $0.84(0.60,1.15)$ \\
\hline Others & & & $0.84(0.47,1.43)$ \\
\hline None & & & $0.91(0.70,1.77)$ \\
\hline
\end{tabular}

Those who replied Yes to the question: (1) Does your work involve vigorous activity that causes large increase in breathing or heart rate; or (2) Does your work involve moderate-intensity activity that causes small increases in breathing or heart rate such as brisk walking or carrying light loads for at least $10 \mathrm{~min}$ continuously?

a Model was simultaneously adjusted for age

${ }^{b}$ Model was simultaneously adjusted for age, gender, health insurance coverage, education level 
Table 6

Odds ratio for doing some travel related PA (Yes to travel related PA) by years lived in US

\begin{tabular}{|c|c|c|c|}
\hline & $\begin{array}{l}\text { Crude odds } \\
\text { ratio }\end{array}$ & $\begin{array}{l}\text { Adjusted odds ratio for doing some } \\
(>10 \text { min) } \\
\text { travel related } \mathrm{PA}^{a}\end{array}$ & $\begin{array}{l}\text { Adjusted odds ratio for doing some (>10 min) } \\
\text { travel related } \mathrm{PA}^{b}\end{array}$ \\
\hline \multicolumn{4}{|l|}{ Years lived in United States } \\
\hline 5 years & Reference & Reference & Reference \\
\hline $6-15$ years & $0.99(0.76,1.29)$ & $0.98(0.75,1.27)$ & $1.05(0.80,1.38)$ \\
\hline$>15$ years & $1.17(0.89,1.54)$ & $1.01(0.75,1.34)$ & $0.94(0,1.02)$ \\
\hline \multicolumn{4}{|l|}{ Age } \\
\hline$\leq 40$ & & Reference & Reference \\
\hline $40-60$ & & $0.95(0.70,1.29)$ & $0.99(0.73,1.34)$ \\
\hline 80 & & $1.86(1.30,2.67)$ & $1.24(0.80,1.93)$ \\
\hline \multicolumn{4}{|l|}{ Gender } \\
\hline Female & & & Reference \\
\hline Male & & & $0.78(0.62,0.99)$ \\
\hline \multicolumn{4}{|l|}{ Employment status } \\
\hline Employed & & & Reference \\
\hline Unemployed & & & $1.20(0.84,1.72)$ \\
\hline Retired & & & $1.69(1.07,2.67)$ \\
\hline Housewife & & & $1.11(0.75,1.68)$ \\
\hline \multicolumn{4}{|l|}{ Education } \\
\hline No school & & & $0.58(0.22,1.52)$ \\
\hline Elementary (1-6 years) & & & $0.74(0.52,1.07)$ \\
\hline High school (7-12 years) & & & $0.94(0.72,1.21)$ \\
\hline College and above ( $>12$ years) & & & Reference \\
\hline \multicolumn{4}{|l|}{ Health insurance } \\
\hline Government & & & Reference \\
\hline Private & & & $0.73(0.51,1.05)$ \\
\hline Others & & & $0.83(0.44,1.57)$ \\
\hline None & & & $0.57(0.43,0.77)$ \\
\hline Unknown & & & $0.54(0.10,2.76)$ \\
\hline
\end{tabular}

Those who replied Yes to the question: Do you walk or use a bicycle (pedal cycle) for at least 10 min continuously to get to and from places?

${ }^{a}$ Model was simultaneously adjusted for age

$b_{\text {Model was simultaneously adjusted for age, gender, employment status, health insurance coverage, education level }}$ 